\title{
Imprint of a dissolved cobalt basaltic source on the Kerguelen Plateau
}

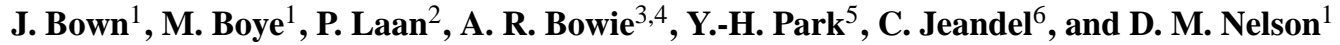 \\ ${ }^{1}$ Institut Universitaire Européen de la Mer, UMS3113, CNRS - Laboratoire des Sciences de l'Environnement MARin, \\ Technopôle Brest Iroise, 29280 Plouzané, France \\ ${ }^{2}$ Royal Netherlands Institute for Sea Research (NIOZ), Department of Marine Chemistry and Geology, \\ Texel, The Netherlands \\ ${ }^{3}$ Antarctic Climate and Ecosystems Cooperative Research Centre (ACE CRC), University of Tasmania, Private Bag 80, \\ Hobart, TAS 7001, Australia \\ ${ }^{4}$ Institute for Marine and Antarctic Studies (IMAS), University of Tasmania, Private Bag 129, Hobart, TAS 7001, Australia \\ ${ }^{5}$ LOCEAN/USM 402, Département Milieux et Peuplements Aquatiques, Muséum d'Histoire Naturelle, 43 rue Cuvier, \\ 75231 Paris Cedex 05, France \\ ${ }^{6}$ LEGOS, UMR5566, Université de Toulouse, CNRS-CNES-IRD, Observatoire Midi-Pyrénées, 14 av. Edouard Belin, \\ 31400 Toulouse, France
}

Correspondence to: J. Bown (johann.bown@univ-brest.fr)

Received: 7 May 2012 - Published in Biogeosciences Discuss.: 19 June 2012

Revised: 6 November 2012 - Accepted: 1 December 2012 - Published: 19 December 2012

\begin{abstract}
Processes of cobalt (Co) entrainment from shelf sediments over the Kerguelen Plateau were studied during the KEOPS (Kerguelen Ocean Plateau compared Study) in order to explain the exceptionally high dissolved cobalt concentrations that have been measured in the surface waters above the Kerguelen Plateau, and in intermediate and deep waters above its eastern slope. Lateral advection and dissolution of Co contained in basalt sediments around Heard Island, a main source of lithogenic Co in the study area, were shown to imprint the process of surface enrichment over the plateau. Dissolved Co enrichment was strongest at the intercept of the eastern slope with intermediate and deep waters, probably due to more efficient mobilisation of the sediments in the slope current, in addition to advection of Co-enriched and low-oxygenated ocean water masses.

In surface waters, the strong sedimentary Co inputs were estimated to be much higher than biological Co uptake in phytoplankton blooms, underlining the potential use of dissolved cobalt as tracer of the natural iron fertilization above the Kerguelen Plateau. Based on a simple steady-state balance equation of the external input of dissolved iron over the plateau, the fertilization of iron inferred by using dissolved Co as a tracer of basalt sources is estimated to be
\end{abstract}

$28 \times 10^{2} \pm 21 \times 10^{2} \mathrm{tyr}^{-1}$ in surface waters of the Kerguelen Plateau. This estimate is consistent with preceding ones (Zhang et al., 2008; Chever et al., 2010), and the calculated iron supply matches with the phytoplankton demand (Sarthou et al., 2008).

\section{Introduction}

Sediment inputs and transport from continental margins, islands, and shelf areas have been identified as important sources of dissolved cobalt (DCo) to the open ocean (Noble et al., 2008, 2012; Bown et al., 2011). However, the processes of Co release from sediments and advection of Co-enriched intermediate and deep waters are poorly constrained. For instance, significant thermally driven water-rock circulation through porous basalt, as inferred from excess ${ }^{223} \mathrm{Ra}$ measurements (Moore et al., 2008; van Beek et al., 2008), can contribute to the release of DCo from basaltic rock at intermediate depths, as exemplified in the Pacific waters surrounding the Hawaiian Islands (Noble et al., 2008). Furthermore, advection of DCo-enriched intermediate and deep waters from continental shelf and slope can be favoured by 
the low oxygenation of waters (Noble et al., 2008; Bown et al., 2011) as well as by microbial reductive processes (Saito et al., 2004). These studies intrinsically suggest that DCo may imprint the sedimentary source in intermediate and deep ocean waters. However, the processes of Co entrainment from shelf sediments have not been extensively studied. These issues were addressed during the KEOPS (KErguelen Ocean Plateau compared Study) cruise in order to better understand if cobalt could also be released from lithogenic material weathered from Heard Island and if cobalt entrainment could generate high DCo concentrations in the upper waters of the shallow plateau and at intermediate and deep depths on the eastern slope.

Cobalt and iron $(\mathrm{Fe})$ are both known to be essential micronutrients in the ocean as they are involved in biological functions that allow phytoplankton growth (Morel et al., 2003). Culture studies have also shown that $\mathrm{Co}$ and Fe requirements are species specific; cyanobacteria have a strict $\mathrm{Co}$ requirement for growth while $\mathrm{Fe}$ demand for diatom growth is much higher than that for Co (Sunda and Hunstmann, 1995; Saito and Moffett, 2002). Their chemistry could show similarities in seawater, since both elements are redox sensitive and they can occur in two different oxidation states $(+\mathrm{II}$ or $+\mathrm{III})$ depending on seawater oxygenation (Boye et al., 2006; Ellwood and van den Berg, 2001; Saito and Moffett, 2001). Moreover Co and Fe have been shown to be strongly complexed by organic ligands, which can impact their respective bioavailability and residence time in the water column (Boye et al., 2001; Saito and Moffett, 2001; Ellwood and van den Berg, 2001; Bown et al., 2012). Despite $\mathrm{Co}$ and $\mathrm{Fe}$ having similar residence times in the whole ocean (Bruland et al., 1994; Saito and Moffett, 2002), Co can exhibit contrasted vertical distributions (e.g. nutrient-like, scavenged-like and/or conservative) depending on oceanic regions, whereas $\mathrm{Fe}$ generally shows nutrient-like distribution and inter-basin fractionation in intermediate and deep waters (Johnson et al., 1997). The different distributions of $\mathrm{Co}$ and $\mathrm{Fe}$ in the ocean suggest that their sources and removal processes may differ in nature and intensity at some point.

Previous studies have proposed different mechanisms for the natural iron fertilization of surface waters over the Kerguelen Plateau (Blain et al., 2008a, b; Chever et al., 2010). However, only this last study proposes a comprehensive budget considering both particulate and dissolved $\mathrm{Fe}$, suggesting that the predominant source of $\mathrm{Fe}$ above the Kerguelen Plateau may be lateral advection of waters that have been in contact with the shallow shoal around Heard Island (Chever et al., 2010). Indeed, this hypothesis was first raised by indirect geochemical tracers: rare earth element (REE) concentrations and radium activities strongly suggested that lateral advection of lithogenic materials weathered from Heard Island could be an important source of dissolved $\mathrm{Fe}(\mathrm{DFe})$ for the water surrounding the plateau (van Beek et al., 2008; Zhang et al., 2008). Also, regeneration from sinking biogenic materials and input from bottom sediments have been proposed as important processes generating high $\mathrm{DFe}$ in the deeper waters below $150 \mathrm{~m}$ over the plateau (Blain et al., 2008b). Park et al. (2008b) suggested that diapycnal mixing enhanced by internal tides and convective winter mixing constitute the dominant mechanisms that make the deep Fe available for phytoplankton in surface waters in austral spring and summer. However, a short-term Fe budget by Sarthou et al. (2008) indicates that the vertical mixing process alone could not match the phytoplankton DFe demand and other mechanisms such as the dissolution of lithogenic $\mathrm{Fe}$ are required. The last part of the present study focuses on the latter mechanism, providing another estimate of the lithogenic $\mathrm{Fe}$ supply to the waters of the Kerguelen Plateau, based on the observed distribution of Co.

\section{Materials and methods}

\subsection{Study area}

The KEOPS cruise was conducted around Kerguelen Island (Southern Ocean) in austral summer from 19 January to 13 February 2005, aboard French R/V Marion Dufresne. The primary objective of the KEOPS cruise was to demonstrate that the high-chlorophyll region located above the Kerguelen Plateau (Blain et al., 2007) is an area that is naturally fertilized in iron (Blain et al., 2008a). This area is characterized by recurrent phytoplankton blooms occurring during the whole austral summer (Blain et al., 2007), and at the time of the KEOPS study the bloom event was dominated by large diatoms (Armand et al., 2008) and characterized by Chl $a$ concentrations up to $3 \mathrm{mg} \mathrm{L}^{-1}$ (Uitz et al., 2009). The Kerguelen Plateau constitutes a major barrier to the eastwardflowing Antarctic Circumpolar Current, and its large-scale circulation (Fig. 1) has been previously described by Park et al. (2008a). Briefly, above the shallow plateau the water circulates anticyclonically at $3-5 \mathrm{~cm} \mathrm{~s}^{-1}$ following bottom topography (Park et al., 2008a). The shallow plateau is surrounded by stronger currents (up to $18 \mathrm{~cm} \mathrm{~s}^{-1}$ ) such as the Fawn Trough Current in the south and its northwestward branch that circulates along the eastern slope of the northern Kerguelen Plateau (Park et al., 2008a).

\subsection{Sampling and methods}

Seawater samples for the determination of DCo concentrations were collected at seven stations shown in Fig. 1. Stations A01 and A03 were located over the shallow plateau (bottom depths: $\sim 500-600 \mathrm{~m}$, Fig. 2) and are representative of the diatom bloom conditions (Armand et al., 2008; Uitz et al., 2009), while C01 was the shallowest station (bottom depth: $\sim 150 \mathrm{~m}$ ) near Heard Island (Fig. 1). Stations A07, $\mathrm{A} 08$, and $\mathrm{C} 11$ were located above and at the end of the eastern slope, and station A11 in oceanic waters (e.g. not influenced by the plateau). Samples were collected using acidcleaned 12-L Go-Flo bottles mounted on a Kevlar line, in an 


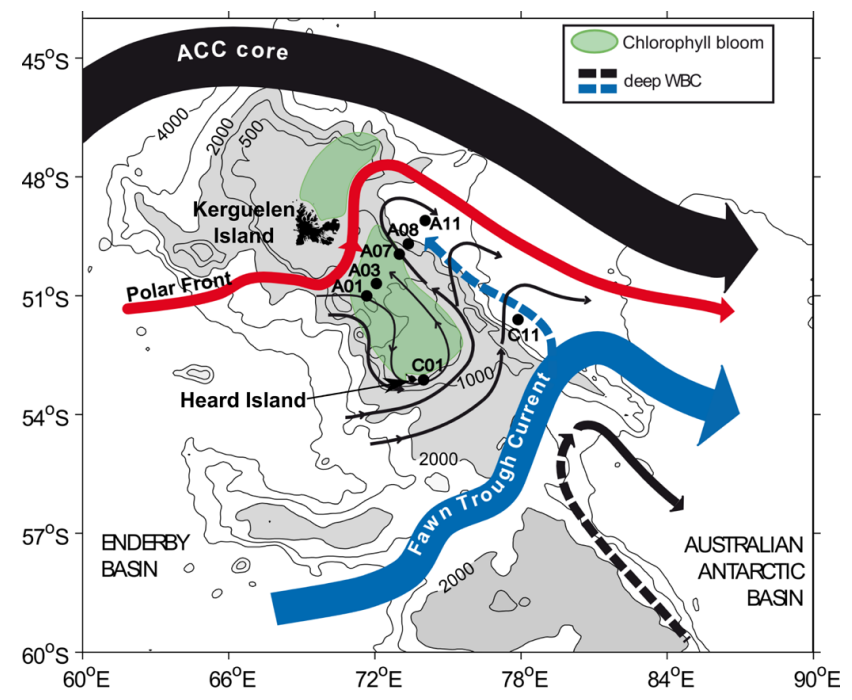

Fig. 1. Sampling locations for dissolved cobalt during the KEOPS cruise (black circles) with bloom location (green area), the bathymetry of the Kerguelen Archipelago and the general circulation (arrows). ACC: Antarctic Circumpolar Current; WBC: western boundary current (Park et al., 2008b).

over-pressurized class 100 clean-air container, after on-line filtration through Sartobran cartridges $(0.2 \mu \mathrm{m}$ with $0.4 \mu \mathrm{m}$ prefilter, Sartorius) under a high-purity nitrogen pressure of 0.5 bar. Filtered samples were acidified at sea to $\mathrm{pH} \sim 2.0$ with ultrapure hydrochloric acid ( $\mathrm{HCl}$, Merck), and stored in double bags at room temperature until shore-based measurements $5 \mathrm{yr}$ after the cruise.

DCo concentrations were measured in acidified and UVdigested samples by flow injection analysis (FIA) and chemiluminescence detection, following the method of Bown et al. (2011) adapted from Shelley et al. (2010). The method includes UV oxidation of the acidified sample $(30 \mathrm{~mL})$ for $3 \mathrm{~h}$ in clean silica tubes using a $600 \mathrm{~W}$ high-pressure mercuryvapour lamp and an equilibration time of $48 \mathrm{~h}$ before analysis (Noble et al., 2008; Bown et al., 2011). The mean reagent blank (based on all blank determinations) in Milli-Q water was $6.70 \pm 1.20 \mathrm{pM}(n=12)$. The mean detection limit of the method, estimated as three times the standard deviation of the average reagent blank, was $3.60 \mathrm{pM}(n=12)$. DCo concentration ([DCo]) data are presented in Table 1.

Samples for the determination of the particulate cobalt concentrations (PCo) were collected only at stations A03, A11 and C11 using the same Go-Flo samplers on separate deployments, which were overpressurised with highpurity nitrogen at $\sim 0.5$ bar. Suspended particulate material was collected on acid-washed $47-\mathrm{mm} 0.2-\mu \mathrm{m}$ polycarbonate membranes (Nuclepore) housed in Teflon PTFE in-line filter holder. Typically $2-10 \mathrm{~L}$ of seawater were passed across the filter, depending on the suspended particulate load. Gentle suction was applied to the base of the filter holder to remove residual seawater; filter membranes were dried under a class
100 laminar flow hood and then stored in acid-washed Petri dishes until analysis in the shore-based laboratory. Particulate Co concentrations were measured using magnetic sector inductively coupled plasma-mass spectrometer (ICP-MS) following strong acid digestion (using a mixture of nitric and hydrochloric acids), following methods published in Bowie et al. (2010) and Cullen and Sherrell (1999).

\section{Results and discussion}

\subsection{Origin and process of dissolved cobalt enrichment in surface waters of the Kerguelen Plateau and above its eastern slope}

The vertical distribution of DCo over the shallow plateau shows a different behaviour depending on station location (Fig. 2). DCo exhibit a vertically homogeneous distribution at A01, except for an increase just above the bottom (up to $\sim 100 \mathrm{pM}$, Fig. 2) and a complete homogenization from the surface to the bottom at $\mathrm{C} 01$ near Heard Island. In contrast, vertical DCo distributions show anomalous concentration maxima ( 175-300 pM, Table 1, Fig. 2) confined in the surface layer at A03, A07 and A08, below which the concentration is either homogenous until a slight increase at the bottom (A03), or increases with depth and reaches highest DCo levels (200-400 pM) at the intercept of the eastern slope with intermediate and deep waters (A07 and A08, Table 1, Fig. 2). At the end of the eastern slope (station C11), high DCo values $(150-200 \mathrm{pM})$ were also found in the surface layer (Fig. 2), and at depths between 500 and $600 \mathrm{~m}$ (Fig. 2) corresponding to the minimum oxygen core $\left(160-170 \mu \mathrm{mol} \mathrm{L}^{-1}\right.$, Fig. 2) of the Upper Circumpolar Deep Water (Park et al., 2008b, 2009). In contrast DCo exhibited a nutrient-like vertical distribution at station A11 where the lowest DCo concentration $(19.0 \pm 1.06 \mathrm{pM}$, Figs. $2-3)$ was measured in the euphotic layer ( $40 \mathrm{~m}$ depth, Fig. 2). All of the anomalous high DCo concentrations measured over the plateau and the eastern slope were much higher than the concentrations measured at the open-ocean reference station $\mathrm{A} 11$, which ranged from 19 to $75 \mathrm{pM}$ (Table 1, Fig. 2). These DCo levels were also higher than the highest cobalt concentrations previously reported in oceanic waters $(50-80 \mathrm{pM})$ influenced by advection from lithogenic sources (Noble et al., 2008; Bown et al., 2011), but on the same order of magnitude as those recently recorded close to the Namibian coast (100-200 pM; Noble et al., 2012).

High positive horizontal gradients (increasing in the upstream direction) in DCo were consequently observed in the surface layer $(<150 \mathrm{~m})$ from C01 to A03, to A07 and to A08 and above the eastern slope in intermediate and deep waters between $\mathrm{C} 11$ and $\mathrm{A} 08$ (0.62, 0.37, 0.21 and $0.59 \mathrm{pmol} \mathrm{m}^{-4}$ respectively). Because the waters that flow anticyclonically above the shallow slope $(<500 \mathrm{~m})$ widely developed around Heard Island (Park et al., 2008b), this indicates that DCo 

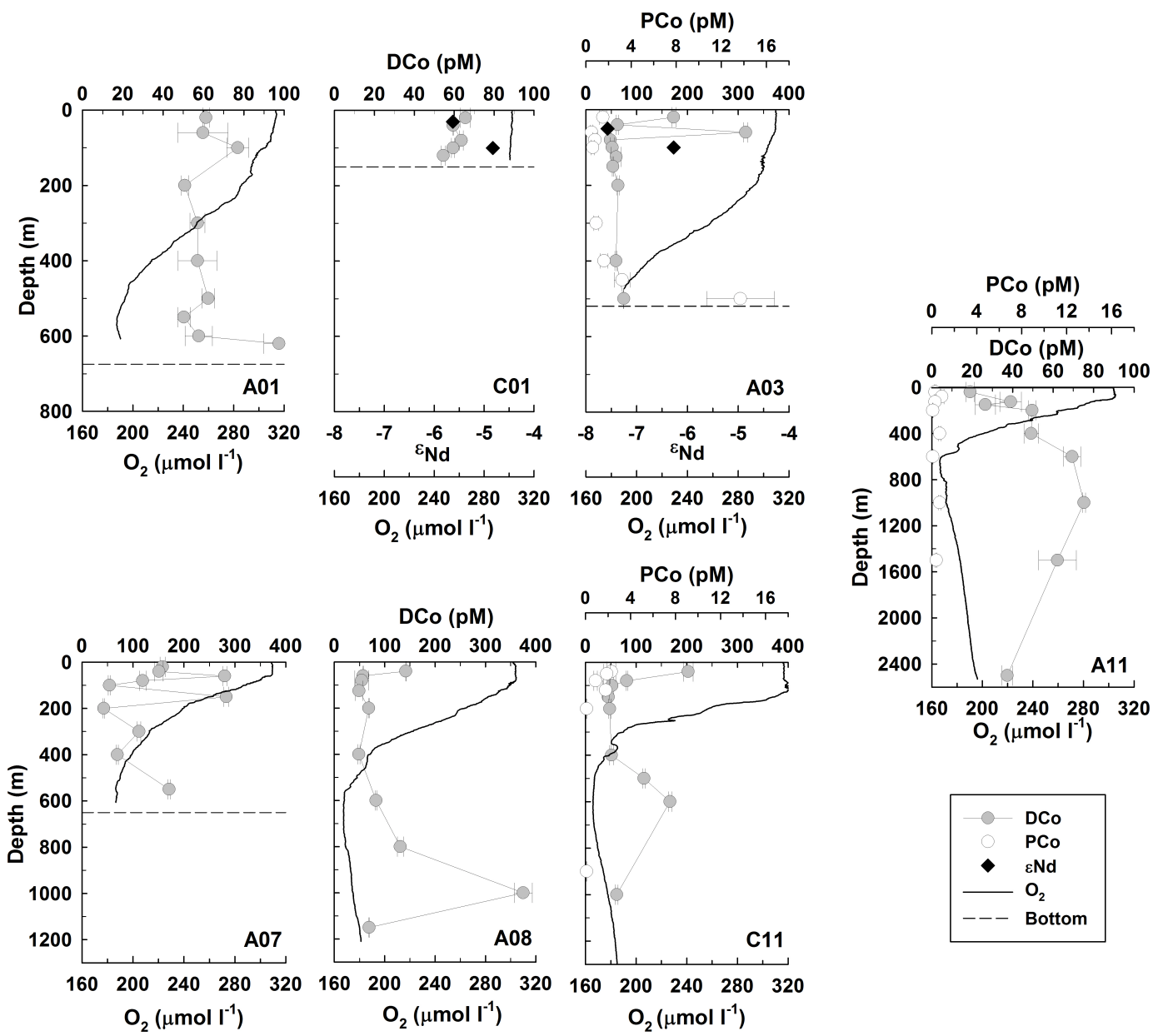

Fig. 2. Distribution of dissolved (DCo, pM), and particulate (PCo, pM) cobalt, dissolved $\left(\mathrm{O}_{2} \mu \mathrm{mol} \mathrm{L}-1\right)$ and dissolved neodymium isotopic composition $(\varepsilon \mathrm{Nd})$ during the KEOPS survey. The DCo error bars represent the standard deviation of triplicate analysis. The PCo error bars were calculated according to error percentages (A03: $\pm 21.8 \%$; A11: $\pm 19.6 \%$; $\mathrm{C} 11: \pm 16.5 \%$ ), which are based on duplicate analysis of individual digestions of the same sample.

source(s) may exist between $\mathrm{C} 01$ and A03, A07, A08, generating high DCo concentration in the surface waters. In the same manner, DCo inputs are occurring in intermediate and deep waters that flow along the eastern slope between stations $\mathrm{C} 11$ and A07, A08.

In order to investigate the origin and processes yielding the DCo enrichment in the surface waters of the plateau, especially between $\mathrm{C} 01$ and $\mathrm{A} 03$ located near Heard Island and in the centre of the diatom bloom, respectively (Armand et al., 2008), we constructed comparative biogeochemical cobalt budgets based on two vertical layers separated by the depth $150 \mathrm{~m}$ (Fig. 4), following the general water circulation on the plateau (described by Park et al., 2008b). Cobalt budgets have also been constructed following the upstream-downstream circulation between stations $\mathrm{C} 11$ and A07-A08 to identify which processes drive the DCo enrichment recorded above the eastern slope of the plateau (Fig. 5).

\subsubsection{Dissolved Co enrichment in surface waters of the plateau}

\section{Evidence of a lithogenic source in the vicinity of Heard Island}

Other trace elements, such as dissolved REE, radium isotopes and total dissolvable $\mathrm{Fe}$, exhibit their highest concentrations at $\mathrm{C} 01$, indicative of a nearby lithogenic source (Blain et al., 2008b; van Beek et al., 2008; Zhang et al., 2008; Chever et al., 2010). Furthermore, the dissolved neodymium (Nd) isotopic composition at $\mathrm{C} 01\left(-6 \leq \varepsilon_{\mathrm{Nd}} \leq-4\right.$; Fig. 2) and $\mathrm{A} 03\left(-8 \leq \varepsilon_{\mathrm{Nd}} \leq-6\right.$; Fig. 2) was significantly less negative than in open ocean waters $\left(-10 \leq \varepsilon_{\mathrm{Nd}} \leq-8\right)$, reflecting lithogenic input into $\mathrm{C} 01$ and $\mathrm{A} 03$ stations surface waters (Jeandel et al., 2011).

There are potentially two lithogenic sources of cobalt into the surface waters of the plateau: one is aeolian deposition of terrestrial dust and the other is entrainment from shelf sediments. The atmospheric deposition flux (dry and wet) of total 
Table 1. Dissolved cobalt concentrations ([DCo]) and transmissometry (Trans.) obtained in the Indian sector of the Southern Ocean during the KEOPS cruise in 2005. Errors on the [DCo] (Stdv DCo) were calculated as standard deviation of triplicate measurements of the same sample.

\begin{tabular}{|c|c|c|c|c|}
\hline $\begin{array}{l}\text { Above the } \\
\text { shallow plateau }\end{array}$ & $\begin{array}{l}\text { Depth } \\
\text { (m) }\end{array}$ & $\begin{array}{l}{[\mathrm{DCo}]} \\
(\mathrm{pM})\end{array}$ & $\begin{array}{l}\text { Stdv DCo } \\
(\mathrm{pM})\end{array}$ & Trans. \\
\hline A01 & 20 & 61.2 & 1.68 & 80.13 \\
\hline \multirow[t]{9}{*}{ (bloom core) } & 60 & 59.7 & 12.5 & 80.49 \\
\hline & 100 & 77.0 & 5.49 & 80.05 \\
\hline & 200 & 50.7 & 1.90 & 82.78 \\
\hline & 300 & 57.0 & 3.72 & 83.98 \\
\hline & 400 & 57.0 & 9.58 & 84.37 \\
\hline & 500 & 62.3 & 3.15 & 83.98 \\
\hline & 550 & 50.3 & 3.13 & 83.10 \\
\hline & 600 & 57.6 & 6.72 & 82.98 \\
\hline & 620 & 97.4 & 7.41 & nd \\
\hline $\mathrm{A} 03$ & 20 & 173 & 3.97 & 81.59 \\
\hline \multirow[t]{9}{*}{ (bloom core) } & 40 & 61.8 & 2.00 & 81.45 \\
\hline & 60 & 315 & 4.06 & 81.52 \\
\hline & 80 & 47.8 & 1.42 & 80.44 \\
\hline & 100 & 51.8 & 4.00 & 79.93 \\
\hline & 125 & 59.6 & 10.1 & 79.19 \\
\hline & 150 & 52.9 & 1.16 & 81.38 \\
\hline & 200 & 63.0 & 2.75 & 84.18 \\
\hline & 400 & 59.0 & 2.38 & 86.11 \\
\hline & 500 & 74.3 & 0.30 & nd \\
\hline $\mathrm{C} 01$ & 20 & 65.6 & 2.50 & 78.97 \\
\hline \multirow{4}{*}{ (Heard Island) } & 40 & 59.5 & 0.10 & 79.14 \\
\hline & 80 & 63.6 & 0.90 & 79.74 \\
\hline & 100 & 59.4 & 0.80 & 79.30 \\
\hline & 120 & 54.5 & 1.00 & 79.93 \\
\hline
\end{tabular}

(dissolved and particulate) Co (TCo) inferred from direct analyses of the aerosols on the Kerguelen Islands ranges from $0.24 \pm 0.03$ to $0.40 \pm 0.05 \mathrm{nmol} \mathrm{m}^{-2} \mathrm{~d}^{-1}$ (A. Heimburger and R. Losno, LISA, France, personal communication, 2011, see Fig. 3). This deposition flux of TCo is slightly lower than the soluble Co deposition flux observed in the Atlantic sector of the Southern Ocean $\left(0.42-0.66 \mathrm{nmol} \mathrm{m}^{-2} \mathrm{~d}^{-1}\right.$; Bown et al., 2011). Considering a 4-month atmospheric deposition period (which corresponds to the residence time of the waters above the plateau) and assuming $18 \%$ dissolution of the atmospheric supply in surface waters (derived from cumulated solubility of cobalt contained in coal ash dust after 4 months, Thuróczy et al., 2010), such inputs would increase DCo concentrations by 0.036 to $0.058 \mathrm{pM}$ in the $0-150 \mathrm{~m}$ surface layer, hence representing $<0.1 \%$ of the observed DCo increase described above. In other words, aeolian inputs of cobalt are negligible on the Kerguelen Plateau, and they cannot generate surface DCo maxima observed at A03, A07 and A08. Therefore, the latter DCo maxima most likely originate from the entrainment of shelf sediments, consistent with the surface circulation scheme and with the conclusions
Table 1. Continued.

\begin{tabular}{|c|c|c|c|c|}
\hline $\begin{array}{l}\text { Above the } \\
\text { eastern slope }\end{array}$ & $\begin{array}{l}\text { Depth } \\
(\mathrm{m})\end{array}$ & $\begin{array}{l}{[\mathrm{DCo}]} \\
(\mathrm{pM})\end{array}$ & $\begin{array}{l}\text { Stdv DCo } \\
(\mathrm{pM})\end{array}$ & Trans. \\
\hline \multirow[t]{10}{*}{ A07 } & 20 & 158 & 4.89 & 81.77 \\
\hline & 40 & 151 & 8.38 & 81.74 \\
\hline & 60 & 280 & 4.30 & 81.86 \\
\hline & 80 & 119 & 6.24 & 82.87 \\
\hline & 100 & 53.9 & 2.42 & 83.69 \\
\hline & 150 & 283 & 4.66 & 84.31 \\
\hline & 200 & 42.6 & 1.34 & 84.63 \\
\hline & 300 & 112 & 3.54 & 85.16 \\
\hline & 400 & 69.3 & 2.12 & 85.30 \\
\hline & 550 & 171 & 2.10 & 85.17 \\
\hline \multirow[t]{10}{*}{ A08 } & 40 & 142 & 0.35 & 82.37 \\
\hline & 60 & 57.0 & 0.68 & 82.39 \\
\hline & 80 & 54.4 & 13.9 & 82.42 \\
\hline & 125 & 49.0 & 7.11 & 84.22 \\
\hline & 200 & 68.4 & 0.50 & 84.85 \\
\hline & 400 & 48.7 & 2.06 & 85.55 \\
\hline & 600 & 82.8 & 1.37 & 85.80 \\
\hline & 800 & 131 & 5.73 & 85.84 \\
\hline & 1000 & 375 & 17.9 & 85.85 \\
\hline & 1150 & 69.2 & 0.74 & 85.90 \\
\hline \multirow[t]{9}{*}{$\mathrm{C} 11$} & 40 & 203 & 9.88 & 83.68 \\
\hline & 80 & 81.3 & 1.47 & 83.69 \\
\hline & 100 & 52.5 & 3.40 & 84.08 \\
\hline & 150 & 45.2 & 1.10 & 85.97 \\
\hline & 200 & 47.8 & 1.83 & 86.31 \\
\hline & 400 & 51.3 & 3.57 & 86.45 \\
\hline & 500 & 116 & 2.85 & 86.54 \\
\hline & 600 & 167 & 3.13 & 86.59 \\
\hline & 1000 & 61.7 & 2.44 & 86.65 \\
\hline $\begin{array}{l}\text { Open-ocean } \\
\text { station }\end{array}$ & $\begin{array}{l}\text { Depth } \\
(\mathrm{m})\end{array}$ & $\begin{array}{l}{[\mathrm{DCo}]} \\
(\mathrm{pM})\end{array}$ & $\begin{array}{l}\text { Stdv DCo } \\
(\mathrm{pM})\end{array}$ & Trans. \\
\hline \multirow[t]{9}{*}{ A11 } & 40 & 19.0 & 2.06 & 79.96 \\
\hline & 125 & 39.0 & 5.37 & 81.53 \\
\hline & 150 & 26.5 & 5.01 & 81.21 \\
\hline & 200 & 49.6 & 1.90 & 81.52 \\
\hline & 400 & 49.2 & 3.66 & 83.46 \\
\hline & 600 & 69.4 & 4.17 & 83.80 \\
\hline & 1000 & 75.3 & 0.70 & 83.39 \\
\hline & 1500 & 62.2 & 9.29 & 83.95 \\
\hline & 2500 & 37.3 & 2.67 & 83.84 \\
\hline
\end{tabular}

derived from other tracers (van Beek et al., 2008; Zhang et al., 2008; Chever et al., 2010). This is also in line with the recent study by Noble et al. (2012) indicating that shallow shelf sediments can be the major source for Co (and Fe) along the Namibian coast. Another potential source can be sporadic water intrusions across the polar front that could have been enriched by Kerguelen Island shelf (Zhang et al., 2008), but the resolution we applied only allows us to describe the entrainment within the anticyclonic circulation from the Heard Island shelf sediments. 

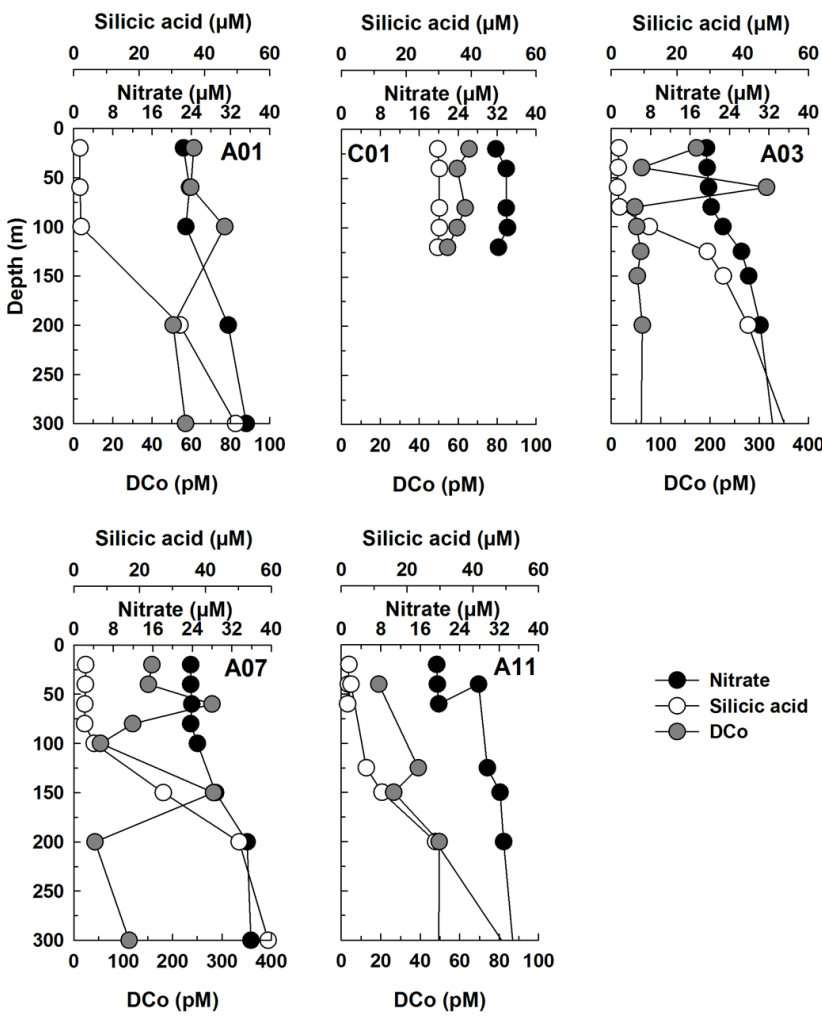

Fig. 3. Distribution of nitrate $(\mu \mathrm{M})$, silicic acid $(\mu \mathrm{M})$ and DCo $(\mathrm{pM})$ in the $0-300 \mathrm{~m}$ depth layer at shallow plateau station in the diatoms bloom core (A01 and A03), over the eastern plateau slope (A07), near Heard Island $(\mathrm{CO1})$ and at the open-ocean station reference A11.

\section{Dissolution of PCo as the main source of DCo in surface waters over the plateau}

The fairly constant DCo concentrations in the $0-150 \mathrm{~m}$ shallow water column of station $\mathrm{C} 01(\sim 60 \mathrm{pM})$, which are significantly higher (Student's t-test, $p<0.001$ ) than at the open ocean reference station A11 $(28.2 \pm 5.80 \mathrm{pM}$, considering the 0-150 m depth layer; see Table 1), suggest that inputs of Co from sediments can impact the whole water column at $\mathrm{C} 01$ (Fig. 2). At A03, and even more pronounced at A01, the increase of DCo observed at the bottom could result from diffusion from bottom sediments (Figs. 2-3). However, this added Co does not likely reach the surface because of the near-zero vertical gradient of DCo below the surface layer. At A07 and A08 the vertical diffusion flux across the pycnocline remains negligible and suggests that the high levels of DCo detected at intermediate and deep depths probably do not impact the surface waters at these stations (Fig. 4). Therefore the local inputs from the bottom are likely not the source of DCo into the surface waters over the plateau (stations A01, A03 and A07) except at station C01 where the water column was shallow enough and well mixed. Hence the lateral advection from $\mathrm{C} 01$ is the most likely process explaining the DCo enrichment at A03, A07 and A08.
Transmissometry can be used as a proxy for particulate material, and the lowest values recorded in the shallow water column at station $\mathrm{C} 01$ suggest that station $\mathrm{C} 01$ was the most impacted by particles (Table 1). At this station, particles are thought to be mainly lithogenic in origin due to the proximity of Heard Island (Fig. 1) and the apparently low biological activity (as evidenced by the absence of macronutrient depletion, Fig. 3). The suspended PCo concentration that would be released from mechanical weathering of the basalt has been estimated by using the particulate Nd concentration measured at $\mathrm{C} 01$ (see legend in Fig. 4), because no direct measurement of PCo was available at this station. This calculation leads to an estimated PCo concentration of $580 \pm 360 \mathrm{pmol} \mathrm{L}^{-1}$ at $20 \mathrm{~m}$ depth at $\mathrm{C} 01$, indicating that $\mathrm{PCo}$ could be extremely high around Heard Island and that weathering of basalts could be a major source of PCo at the study site. To test this estimation, we calculate PCo concentration in the surface waters of A03 ([PCo $\left.]_{\text {estimated }}=1.6 \pm 1.0 \mathrm{pM}\right)$ using the same mode of calculation as at $\mathrm{C} 01$, and the computed concentration reasonably agrees with the direct measurement of PCo at A03 ([PCo $]_{\text {measured }}=0.85 \pm 0.23 \mathrm{pM}$ ). Therefore basaltic sediments could be an important source of Co for plateau waters circulating downstream from the island, as they are for REE (Zhang et al., 2008) and Fe (Blain et al., 2008b; Chever et al., 2010). Dissolved Nd isotopic composition of the waters at $\mathrm{C} 01\left(-6 \leq \varepsilon_{\mathrm{Nd}} \leq-4\right.$; Fig. 2) (Jeandel et al., 2011) further supports the enrichment of plateau waters from basaltic sediments $\left(\varepsilon_{\mathrm{Nd}} \sim-2\right)$ (Weis et al., 2002; Doucet et al., 2005). This is consistent with the REE and radium isotope distributions showing that lateral advection of inputs from the Heard Island shelf in surface waters from $\mathrm{C} 01$ to $\mathrm{A} 03$ is possible and consistent with physical observations (Park et al., 2008a, b; van Beek et al., 2008).

The advection of DCo alone from C01 toward the other stations of the plateau does not account for the surface enrichment observed at A03, A07 and A08. Indeed the significant positive DCo gradient of $0.62 \mathrm{pmol} \mathrm{m}^{-4}$ between $\mathrm{C} 01$ and A03 needs to be explained. The budget proposed in Fig. 3 allows estimating a concomitant loss of PCo of $995 \pm 905 \mathrm{nmol} \mathrm{m}^{-2} \mathrm{~d}^{-1}$ between these two stations (using $[\mathrm{PCo}]_{\text {mean }}=0.85 \pm 0.23 \mathrm{pM}$ at A03, standard error, $\left.n=4\right)$. Two potential processes could remove PCo from the surface waters: the dissolution of $\mathrm{PCo}$ (thus production of $\mathrm{DCo}$ ) and its removal by physico-chemical processes (e.g. particle aggregation, precipitation and sinking). The significant positive advective term calculated for DCo between $\mathrm{C} 01$ and $\mathrm{A} 03$ $\left(581 \pm 142 \mathrm{nmol} \mathrm{m}^{-2} \mathrm{~d}^{-1}\right.$, Fig. 4) supports the dissolution hypothesis. Furthermore, the dissolution of PCo advected from C01 would increase the initial DCo inventory by $104 \pm 65 \mathrm{pM}$ in surface waters of $\mathrm{A} 03$, considering a dissolution of $\mathrm{PCo}$ of $\sim 18 \%$ derived from the cumulated solubility of cobalt contained in coal ash dust after 4 months (the estimated residence time of the waters flowing on the plateau; Thuróczy et al., 2010). This estimate accounts for about half of the DCo inputs detected in surface waters of A03 (175-300 pM; 


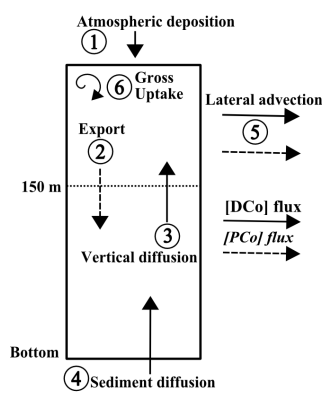

Bottom

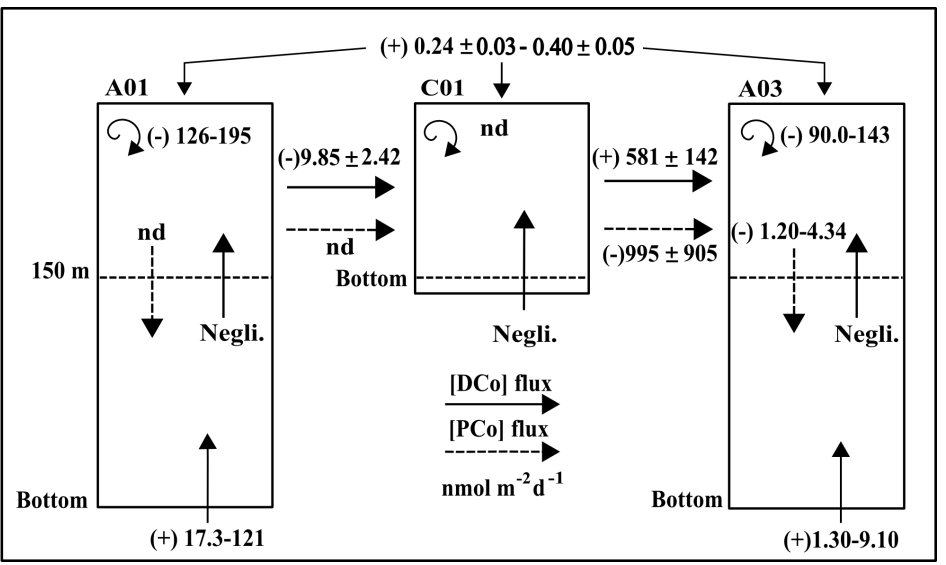

Fig. 4. Budget of dissolved cobalt (DCo) and particulate cobalt (PCo) over the shallow Kerguelen Plateau. All estimated fluxes are in nmol Co m ${ }^{-2} \mathrm{~d}^{-1}$, and based on an assumption of steady state. (1) Total atmospheric Co deposition flux on Kerguelen Island (A. Heimburger and R. Losno, personal communication, 2011). The downward PCo export flux (2) was estimated from PCo measured at A03. The vertical diffusion flux across the pycnocline (3) was negligible at A01 and A03 since there was no gradient of [DCo] within pycnocline. The sediment diffusion flux (4) was determined using the [DCo] gradient in the $20 \mathrm{~m}$ above the bottom and $\mathrm{Kz}$ ranging from $1.010^{-4}$ to $7.010^{-4} \mathrm{~m}^{2} \mathrm{~s}^{-1}$ as determined in bottom waters of the Santa Monica Basin (Johnson et al., 1988). This flux could not been determined at C01 since no [DCo] gradient was observed above the sediment. The lateral advective flux in the top $150 \mathrm{~m}$ (5) was estimated using the gradients of [DCo] and [PCo] between A01 and C01, and between C01 and A03 (only considering DCo inputs at A03) and using a mean current velocity of $4.0 \pm 0.5 \mathrm{~cm} \mathrm{~s}^{-1}$ (Park et al., 2008b). As sediments at C01 are mainly composed of coarse-grained basalts (Viollier et al., 2005), [PCo] at C01 was estimated from the average Co abundance in dredged basalts north of Heard Island of 69.2 \pm 8.60 ppm (standard error, $n=8$ ) (Weis et al., 2002), and by using the particulate Nd concentration measured at C01 (141.3 $\pm 4.6 \mathrm{pM}$ at $20 \mathrm{~m}$ depth; Jeandel et al., 2011) and a mean lithogenic $\mathrm{Co} / \mathrm{Nd}$ ratio of $4.01 \pm 2.40$ (standard error, $n=8$ ), representative of the basalts in the vicinity of Heard Island (Weis et al., 2002). The error bar was calculated by propagating the uncertainties of all variables. The gross uptake by diatoms (6) was estimated from recorded fucoxanthin concentrations (J. Ras and H. Claustre, personal communication, 2011) and the corresponding cobalt uptake rate reported by Saito et al. (2010).

Note: "nd" means not determined; "Negli." means negligible term.
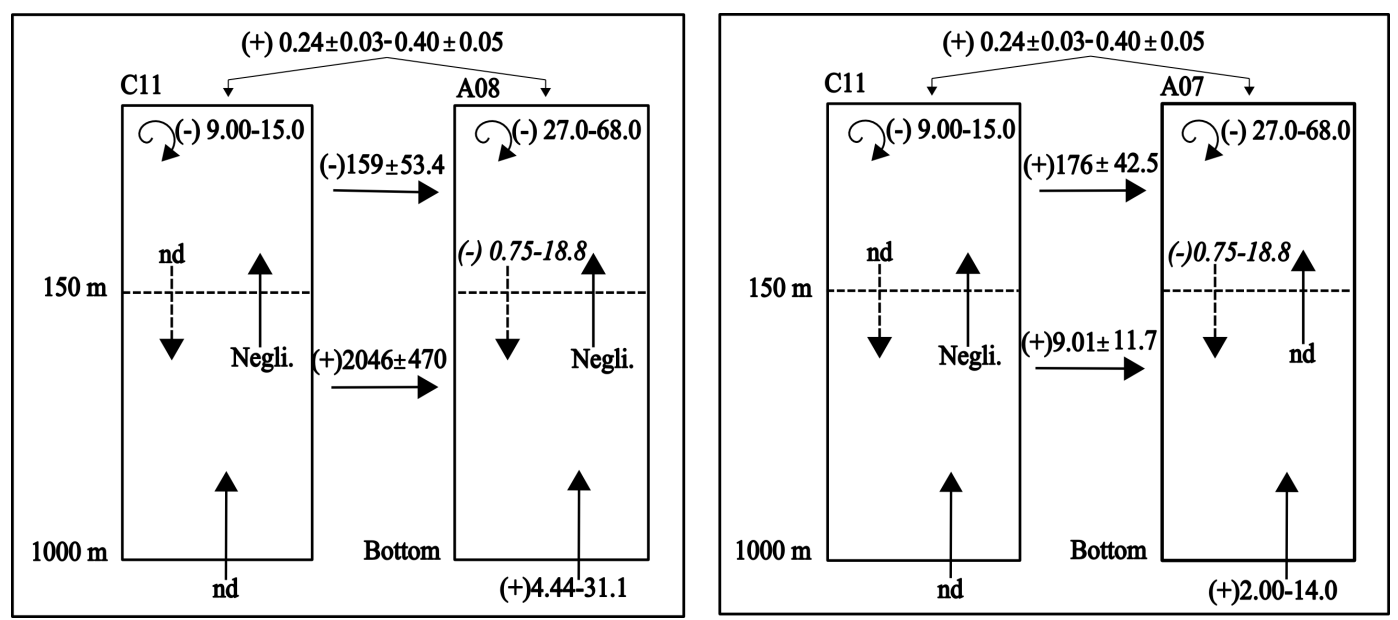

Fig. 5. Budget of DCo and PCo on the eastern slope of the Kerguelen Plateau. All fluxes are in nmol Co m ${ }^{-2} \mathrm{~d}^{-1}$ and estimated for an assumed steady state. All estimates are derived as described in Fig. 3, except the lateral advective fluxes of DCo and PCo (5), which were estimated from cobalt concentrations gradients between C11 and A07 and between C11 and A08 in the 0-150 m depth upper water layer and in the deep water layer between 400 and $1000 \mathrm{~m}$ depth, with a mean current velocity of $0.08 \mathrm{~m} \mathrm{~s}^{-1}$ (Park et al., 2008a). As there are no PCo data available at A07 and A08, the downward PCo export flux (2) was estimated using PCo measured at B05 (closest station with available PCo data).

Note: "nd" means not determined; "Negli." means negligible term. 
Fig. 2), further supporting that dissolution of PCo is a main source of DCo in surface waters of the plateau.

By contrast with DFe, which shows highest values at station C01 near Heard Island (Blain et al., 2008b), DCo was highest in the surface waters above the plateau. The solubility and dissolution kinetics of both $\mathrm{Co}$ and $\mathrm{Fe}$ from basalts in seawater remain unknown and require further investigation. The fraction and the kinetics of Co and Fe release are, however, probably different during dissolution from lithogenic material, as suggested by recent studies conducted on mineral and anthropogenic aerosols (Thuróczy et al., 2010; Shelley et al., 2012) and on riverine basalts (Hausrath et al., 2009). The fractional solubility of Co estimated for atmospheric processed aerosols (10-100\%; Shelley et al., 2012) can be higher than for coal ash or Cape Verde loess $(0.78 \%$ and $0.14 \%$, respectively; Thuróczy et al., 2010), and higher than for Fe (5-45\%; Shelley et al., 2012).

In the latter study, since $\mathrm{Fe}$ is much more abundant than Co in the aerosols $(\mathrm{Fe} / \mathrm{Co} \sim 2500$, E. R. Sholkovitz, personal communication, 2012), even with a lower solubility relative to $\mathrm{Co}$, a larger amount of $\mathrm{Fe}$ would be released from the dissolution of such processed mineral dusts. This contrasts with experimental results on the dissolution of basalt in acidic Milli-Q water $(\mathrm{pH}=6)$, which suggested that the dissolution rate of Co from the basalt $(0.062 \times$ $\left.10^{-16} \mathrm{~mol} \mathrm{~m}^{-2} \mathrm{~s}^{-1}\right)$ is significantly lower than the $\mathrm{Fe}$ release rate $\left(0.11 \times 10^{-16} \mathrm{~mol} \mathrm{~m}^{-2} \mathrm{~s}^{-1}\right)$ (Hausrath et al., 2009). This would indicate that basalt dissolution rates are elementspecific and that Co dissolution could be slower than Fe dissolution, which can partially explain why DCo concentrations do not display their highest values close to C01, suspected to be the most impacted station by the lithogenic inputs from Heard Island for Fe, REE and Ra (Blain et al., 2008b; van Beek et al., 2008; Zhang et al., 2008; Chever et al., 2010). In addition, the organic complexation of DCo may enhance both the basaltic dissolution (Hausrath et al., 2009) and the stabilization of $\mathrm{Co}$ in the dissolved phase as previously observed in the Southern Ocean (Bown et al., 2012). Furthermore, the biological removal term could be much higher for $\mathrm{Fe}$ than for Co above the plateau, as suggested by the absence of a nutrient-like vertical distribution of DCo (Figs. 2-3), since diatoms require much more Fe than Co for growth (Sunda and Huntsman, 1995). This would account for the observed strong positive gradient of DCo (Fig. 3) and a strong negative gradient of DFe in the surface waters of the plateau between Heard Island (station C01) and the core of the bloom (station A03). Finally, regeneration of DCo has been previously suggested to be an important internal Co source that could represent $\sim 70 \%$ of the biological uptake south of the polar front (Bown et al., 2011). Hence, such regeneration processes, associated with the rather low export flux estimated at A03, A07 and A08, would increase the residence time of DCo in surface waters of the shallow plateau.

\subsubsection{Dissolved Co enrichment above the eastern slope of the plateau}

Between C11 and A07, lateral DCo advection was the dominant source flux in the upper layer, contrasting with the DCo sink observed between $\mathrm{C} 11$ and A08 (Fig. 5). The atmospheric input term was calculated to be about equal at A07 and A08 due to the proximity of these stations. We also considered that the biological uptake and export fluxes should be similar as the computed daily primary production rates for the total phytoplankton community ranged between 0.60 and $0.80 \mathrm{gC} \mathrm{m}^{-2} \mathrm{~d}^{-1}$ at these stations (Uitz et al., 2009) (Fig. 5). Nevertheless A07 was shallower and located at the top of the slope (Fig. 4); hence the advection of DCo-enriched surface waters of the plateau reaching this station is also conceivable in addition to advection from $\mathrm{C} 11$. Thus the enrichment of the upper waters between $\mathrm{C} 11$ and A07 may arise from the transport of lithogenic DCo and potential mixing with the upper waters of the plateau that have been shown to be enriched in DCo.

In deeper waters, lateral advection of DCo between C11 and A08 along the eastern slope was the highest source calculated in the present study (2046 $\pm 470 \mathrm{nmol} \mathrm{m}^{-2} \mathrm{~d}^{-1}$, Fig. 5). Mean current velocity along the slope $\left(\sim 0.08 \mathrm{~m} \mathrm{~s}^{-1}\right)$ was twice as high as on the plateau $\left(\sim 0.04 \mathrm{~m} \mathrm{~s}^{-1}\right)$ (Park et al., 2008b, 2009), which in turn may intensify the resuspension of lithogenic particles from deposited sediments. Dissolution of lithogenic particles and advection in the slope current can thus explain the amount of DCo advected from C11 to A08. The DCo entrainment by the slope current may also be promoted in the low-oxygenated Upper Circumpolar Deep water (UCDW) $\left(\mathrm{O}_{2} \sim 160-170 \mu \mathrm{mol} \mathrm{L}^{-1}\right.$, Fig. 2) that flows along the eastern slope. Abiotic reduction of manganese oxides contained into the sediments can indeed produce DCo, which can be released at the sediment-water interface by diffusion from the pore waters (Heggie and Lewis, 1984; Johnson et al., 1988), in addition to the dissolution of resuspended lithogenic particles in the waters above the sediment. Those processes have been evidenced in anoxic conditions (Heggie and Lewis, 1984; Johnson et al., 1988), whereas it is uncertain whether the reductive dissolution is still significant at higher $\mathrm{O}_{2}$ concentrations such as those recorded in the bottom waters of the plateau.

In any event, lower oxygenation of seawater is thought to promote DCo stabilization as it is suggested in several studies that report high DCo concentrations (ranging from 50 to $160 \mathrm{pM}$ ) concomitant with low $\mathrm{O}_{2}$ concentrations that range from $\sim 10-50 \mu \mathrm{mol} \mathrm{L}^{-1}$ in the Atlantic oxygen minimum zone (OMZ; Noble et al., 2012) to $\sim 180 \mu \mathrm{mol} \mathrm{L}^{-1}$ in the UCDW (Bown et al., 2011). The latter study also showed that the organic complexation of DCo would probably promote Co stabilization and its transport from continental margins to the open ocean (Bown et al., 2012). According to the budget at station A08, vertical diffusion from the sediment (4.41$31.1 \mathrm{nmol} \mathrm{m}^{-2} \mathrm{~d}^{-1}$, Fig. 5) combined with lateral advection 
Table 2. Terms to calculate the external inputs of dissolved Co and Fe to the surface waters of the Kerguelen Plateau.

\begin{tabular}{|c|c|}
\hline \multicolumn{2}{|l|}{ Pools } \\
\hline $\begin{array}{l}\text { Mean DCo concentration at A11 (pM) } \\
\left.\text { within } 0-150 \mathrm{~m} \text { depth ([DCo }]_{\text {ocean }}\right) \\
\text { Mean DCo concentration over the plateau } \\
\left.(\mathrm{pM}) \text { within } 0-150 \mathrm{~m} \text { depth ([DCo }]_{\text {plateau }}\right) \\
\text { Water mass depth }(\mathrm{m}) \\
\text { Water mass width }(\mathrm{m}) \\
\text { Current velocity }\left(\mathrm{cm} \mathrm{s}^{-1}\right)^{\mathrm{a}} \\
(\mathrm{Fe} / \mathrm{Co})_{\text {basalt }} \text { ratio }^{\mathrm{b}} \\
(\mathrm{Fe} / \mathrm{Co})_{\text {solubility }} \text { ratio }^{\mathrm{c}} \\
\text { Fluxes }\end{array}$ & $\begin{array}{l}28.2 \pm 5.80 \\
(\text { standard error, } n=3 \text { ) } \\
104 \pm 16.2 \\
\text { (standard error, } n=25 \text { ) } \\
150 \\
350 \times 10^{3} \\
4 \pm 1 \\
652 \pm 98.4 \\
\sim 0.30\end{array}$ \\
\hline $\begin{array}{l}\text { Water flux }\left(F_{\mathrm{W}}, \mathrm{m}^{3} \mathrm{~s}^{-1}\right) \\
\text { DCo external input }\left(F_{\mathrm{DCo}}, \mathrm{tDCo} \mathrm{yr}{ }^{-1}\right)^{\mathrm{d}} \\
\text { DFe external input }\left(F_{\mathrm{DFe}}, \mathrm{tDFe} \mathrm{yr}^{-1}\right)^{\mathrm{e}}\end{array}$ & $\begin{array}{l}(2.0 \pm 0.50) \times 10^{6} \\
287 \pm 175 \\
(28 \pm 21) \times 10^{2}\end{array}$ \\
\hline $\begin{array}{l}\text { from Park et al. }(2008 \mathrm{~b}) ; \\
\text { obtained for Keremis dredged basalts (samplest } \\
\text { a }(\mathrm{Fe} / \mathrm{Co})_{\text {solubility }} \text { ratio of } \sim 0.30 \text { was used base } \\
\text { Co from saharan aerosols in acidified Milli-Q wa } \\
2012) ; \\
F_{\mathrm{DCo}}=F_{\mathrm{W}} \cdot\left([\mathrm{DCo}]_{\text {plateau }}-[\mathrm{DCo}]_{\text {ocean }}\right) \\
F_{\mathrm{DFe}}=F_{\mathrm{DCoinput}} \cdot(\mathrm{Fe} / \mathrm{Co})_{\text {solubility }} \cdot(\mathrm{Fe} / \mathrm{Co})_{\mathrm{b}} \\
\text { explanation). }\end{array}$ & $\begin{array}{l}\text { 6), from Weis et al. (2002); } \\
\text { solubility rates for Fe and } \\
H=5.5 \text { ) (Shelley et al., } \\
5 \% \text { (see text for }\end{array}$ \\
\hline
\end{tabular}

of DCo from C11, might significantly increase DCo concentrations in the UCDW water mass located between 600 and $1000 \mathrm{~m}$ depth (Fig. 2). At A07, the vertical diffusion of DCo from bottom sediments was less intense than at A08 (2.0$14.0 \mathrm{nmol} \mathrm{m}^{-2} \mathrm{~d}^{-1}$ between 550 and $200 \mathrm{~m}$ depth, Fig. 5). Consequently the enrichment was more important at the intercept of the eastern slope in intermediate and deep waters (station A08, Fig. 2). The elevated DCo levels recorded in the UCDW at C11 could also be due to enrichment in DCo and its stabilization as this water mass flowed within the Antarctic Circumpolar Current and across the Fawn Trough Current, similarly to previous observations in UCDW at other locations (Bown et al., 2011).

\subsection{Sedimentary inputs of dissolved Fe as inferred from Co entrainment fluxes}

Dissolved Fe concentrations (DFe) in the surface layer over the plateau in late summer indicate that removal terms such as biological uptake by phytoplankton and/or abiotic scavenging are high enough to mask the sedimentary inputs of DFe in surface waters (Blain et al., 2008b; Chever et al., 2010). Contrastingly, lateral advection of DCo in surface waters at A03 was much higher than either the biological uptake of DCo or the downward particulate export fluxes (Fig. 4), which makes possible the use of DCo as a tracer to estimate the lithogenic DFe input into the bloom. To derive this estimate, we propose using the same approach as Zhang et al. (2008). Assuming steady state and mass conservation, the external input of DCo into the bloom, $F_{\mathrm{DCo}}$, can be written as

$F_{\mathrm{DCo}}=F_{\mathrm{w}} \times\left([\mathrm{DCo}]_{\text {plateau }}-[\mathrm{DCo}]_{\text {ocean }}\right)$

where $F_{\mathrm{w}}$ stands for a mean water flux through the surface layer $(0-150 \mathrm{~m})$ over the plateau, $[\mathrm{DCo}]_{\text {plateau }}$ is the mean DCo concentration in the surface layer averaged over the whole plateau shallower than $1000 \mathrm{~m}$, and [DCo] $]_{\text {ocean }}$ is the surface layer DCo concentration at A11, the open ocean reference station (Table 1). $F_{\mathrm{w}}$ is estimated as $2.0 \pm 0.5 \mathrm{~Sv}$ $\left(1 \mathrm{~Sv}=10^{6} \mathrm{~m}^{3} \mathrm{~s}^{-1}\right)$ based on the top-to-bottom water transport associated with the anticyclonic circulation over the northern Kerguelen Plateau of 4 Sv (Park et al., 2009), and considering the surface intensification of geostrophic currents suggesting a roughly equal partition of water flux above and below $150 \mathrm{~m}$ (Park et al., 2008a). The error bar of $F_{\mathrm{w}}$ corresponds to the $25 \%$ errors in estimation of mean currents (Park et al., 2008a). Finally, the external DFe input flux, $F_{\mathrm{DFe}}$, was estimated as $F_{\mathrm{DCo}}$ multiplied by the ratio of relative abundances of $\mathrm{Fe}$ to $\mathrm{Co}$ in basalts, their solubility ratio, and considering that DFe accounts for $5 \%$ of the total $\mathrm{Fe}$ (dissolved + particulate) above the plateau (Chever et al., 2010): $F_{\mathrm{DFe}}=F_{\mathrm{DCo}} \times(\mathrm{Fe} / \mathrm{Co})_{\text {basalt }} \times(\mathrm{Fe} / \mathrm{Co})_{\text {solubility }} \times 5 \%$. All parameter values used in this equation are listed in Table 2 . The resulting external inputs of DFe to the surface waters of the plateau are $(28 \pm 21) \times 10^{2} \mathrm{tDFe} \mathrm{yr}^{-1}$ (Table 2). The error bar was calculated by propagating the uncertainties of all variables indicated in Table 1 . The DFe external input estimated here is close to that estimated independently from

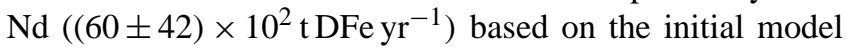
of Zhang et al. (2008), recalculated for the $0-150 \mathrm{~m}$ depth layer and considering that DFe accounts for $5 \%$ of the total Fe above the plateau (Chever et al., 2010).

It is interesting to check whether our estimate is also consistent with the advective DFe supply required to sustain the phytoplankton bloom during KEOPS. Based on the results of Sarthou et al. (2008), Blain et al. (2008b) reported that the net $\mathrm{Fe}$ demand of the phytoplankton community over the plateau is $208 \mathrm{nmol} \mathrm{m}^{-2} \mathrm{~d}^{-1}$, of which $31 \mathrm{nmol} \mathrm{m}^{-2} \mathrm{~d}^{-1}$ are provided by the vertical diffusive supply. The remainder, $177 \mathrm{nmol} \mathrm{m}^{-2} \mathrm{~d}^{-1}$, should then be provided by the combined winter stock and lateral advection. Given the seasonal DFe flux ratio of about 3.36 between winter stock utilisation and vertical diffusive supply according to Table 2 of Blain et al. (2008b), the winter stock should provide as much as $104(=31 \times 3.36) \mathrm{nmol} \mathrm{m}^{-2} \mathrm{~d}^{-1}$ of DFe, leaving $73 \mathrm{nmol} \mathrm{m}^{-2} \mathrm{~d}^{-1}$ for lateral advection. Assuming a bloom surface area over the northern Kerguelen Plateau of the order of $9 \times 10^{10} \mathrm{~m}^{2}$ (or $300 \mathrm{~km} \times 300 \mathrm{~km}$ ), the required annual $\mathrm{Fe}$ supply by lateral advection amounts to $1.310^{2} \mathrm{tyr}^{-1}$. This value is more than an order of magnitude lower than the external DFe input estimated from DCo $\left((28 \pm 21) \times 10^{2} \mathrm{tDFe} \mathrm{yr}^{-1}\right)$, indicating that the external DFe input is more than sufficient for phytoplankton demand. Here the advective DFe flux estimated from the short-term Fe budget can be underestimated by the portion of the DFe winter 
stock, which includes advected (and regenerated) DFe. Furthermore, the flux estimated from DCo can be overestimated as it considered a constant $(\mathrm{Fe} / \mathrm{Co})_{\text {solubility ratio in acidic }}$ Milli-Q water, while recent work on dissolution of other trace metals from basalt in seawater showed more complex dissolution kinetics (C. Jeandel, personal communication, 2011). Despite these uncertainties, rates of advective Fe supply we have estimated on the basis of advective DCo supply are more than sufficient to support the estimated phytoplankton demand in excess of that supplied by other processes. This suggests the potential of DCo as a new tracer of the natural iron fertilization over the Kerguelen Plateau.

Natural fertilization of the ocean can potentially avoid colimitation by trace elements such as $\mathrm{Co}$, which has been earlier postulated for the region downstream of the Galapagos Islands by Martin et al. (1994). Even if Co requirement by diatoms is not as high as $\mathrm{Fe}$ and $\mathrm{Zn}$, the estimated DFe and DCo external inputs discussed above suggest that Fe/Co colimitation is probably avoided by the natural fertilization occurring above the Kerguelen Plateau.

\section{Conclusions}

Basalt weathering in the vicinity of the Heard Island has been identified as the main source of particulate cobalt. This particulate cobalt then partially dissolves during lateral advection to generate the very high DCo concentrations observed in surface waters of the Kerguelen Plateau. Dissolved Co regeneration processes associated with the rather low export flux estimated would increase the residence time of DCo in surface waters of the shallow plateau. Intermediate and deep waters that flow along the eastern slope exhibited even higher DCo concentrations, which can be due to lateral advection of DCo with additional enrichments due to enhanced DCo diffusion at the bottom water sediment interface and enhanced advection and dissolution of PCo.

The lateral advection term for DCo in the surface waters of the plateau is higher than the main sink term linked to biological uptake, indicating that DCo could be used as a potential tracer of the natural iron fertilization in the bloom area. We have obtained encouraging results in estimating the DFe external input from DCo, yielding values larger than the advective supply of DFe that has been estimated to be needed for phytoplankton to bloom over the Kerguelen Plateau (Sarthou et al., 2008). If similar configuration (high sedimentary inputs of both $\mathrm{Fe}$ and $\mathrm{Co}$ into a diatom bloom) occurs in oceanic and/or coastal waters, then it is well conceivable to use DCo as a tracer of DFe source. We believe that future observations of missing data during the 2011 KEOPS-2 experiment (e.g. PCo near Heard Island) and better knowledge on the regional circulation and trace element exchanges between particulate and dissolved phase, especially dissolution kinetics of cobalt from lithogenic material, would further narrow the uncertainties of these estimates.
Acknowledgements. We are grateful to the Project Coordinator Stéphane Blain, to Bernard Quéguiner, the Chief Scientist, and to the captain and crew of R/V Marion Dufresne II for their support on board. We also would like to thank T. Wagener for his help during sampling operations. We warmly thank Mak Saito and an anonymous referee for their constructive review. This work was supported by the Institut National des Sciences de l'Univers (INSU), the French Polar Institute (Institut Polaire Paul Emile Victor, IPEV) and the Antarctic Climate and Ecosystems Cooperative Research Centre. The Region Bretagne was supporting the PhD fellowship of J.B.

Edited by: S. W. A. Naqvi

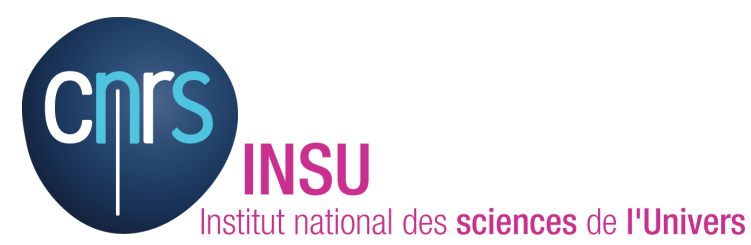

The publication of this article is financed by CNRS-INSU.

\section{References}

Armand, L. K., Cornet-Barthaux, V., Mosseri, J., and Queguiner, B.: Late summer diatom biomass and community structure on and around the naturally iron-fertilised Kerguelen Plateau in the Southern Ocean, Deep-Sea Res. Pt. II, 55, 653-676, 2008.

Blain, S., Quéguiner, B., Armand, L., Belviso, S., Bombled, B., Bopp, L., Bowie, A., Brunet, C., Brussaard, C., Carlotti, F., Christaki, U., Corbière, A., Durand, I., Ebersbach, F., Fuda, J.-L., Garcia, N., Gerringa, L., Griffiths, B., Guigue, C., Guillerm, C., Jacquet, S., Jeandel, C., Laan, P., Lefèvre, D., Lo Monaco, C., Malits, A., Mosseri, J., Obernobsterer, I., Park, Y.-H., Picheral, M., Pondaven, P., Remenyi, T., Sandroni, V., Sarthou, G., Savoye, N., Scouarnec, L., Souhaut, M., Thuiller, D., Timmermans, K., Trull, T., Uitz, J., van Beek, P., Veldhuis, M., Vincent, D., Viollier, E., Vong, L., and Wagener, T.: Effect of natural iron fertilization on carbon sequestration in the Southern Ocean, Nature, 446, 1070-1074, 2007.

Blain, S., Queguiner, B., and Trull, T.: The natural iron fertilization experiment KEOPS (KErguelen Ocean and Plateau compared Study): An overview, Deep-Sea Res. Pt. II, 55, 559-565, doi:10.1016/j.dsr2.2008.01.002, 2008a.

Blain, S., Sarthou, G., and Laan, P.: Distribution of dissolved iron during the natural iron-fertilization experiment KEOPS (Kerguelen Plateau, Southern Ocean), Deep-Sea Res. Pt. II, 55, 594-605, 2008b.

Bowie, A. R., Townsend, A. T., Lannuzel, D., Remenyi, T. A., and van der Merwe, P.: Modern sampling and analytical methods for the determination of trace elements in marine particulate material using magnetic sector inductively coupled plasma mass spectrometry, Anal. Chim. Acta, 676, 15-27, doi:10.1016/j.aca.2010.07.037, 2010.

Bown, J., Boye, M., Baker, A., Duvieilbourg, E., Lacan, F., Le Moigne, F., Planchon, F., Speich, S., and Nelson, D. M.: The biogeochemical cycle of dissolved cobalt in the Atlantic and the 
Southern Ocean south off the coast of South Africa, Mar. Chem., 126, 193-206, doi:10.1016/j.marchem.2011.03.008, 2011.

Bown, J., Boye, M., and Nelson, D. M.: New insights on the role of organic speciation in the biogeochemical cycle of dissolved cobalt in the southeastern Atlantic and the Southern Ocean, Biogeosciences, 9, 2719-2736, doi:10.5194/bg-9-2719-2012, 2012.

Boye, M., van den Berg, C. M. G., de Jong, J., Leach, H., Croot, P., and de Baar, H.: Organic complexation of iron in the Southern Ocean, Deep Sea Res. Pt. I, 48, 1477-1497, 2001.

Boye, M., Aldrich, A., van den Berg, C. M. G., de Jong, J., Nirmaier, H., Veldhuis, M., Timmermans, K., and de Baar, H.: The chemical speciation of iron in the north-east Atlantic Ocean, Deep Sea Res. Pt. I, 53, 667-683, 2006.

Bruland, K., Orians, K., and Cowen, J.: Reactive trace metals in the stratified central North Pacific, Geochim. Cosmochim. Ac., 58, 3171-3182, 1994.

Chever, F., Sarthou, G., Bucciarelli, E., Blain, S., and Bowie, A. R.: An iron budget during the natural iron fertilisation experiment KEOPS (Kerguelen Islands, Southern Ocean), Biogeosciences, 7, 455-468, doi:10.5194/bg-7-455-2010, 2010.

Cullen, J. T. and Sherrell, R. M.: Techniques for determination of trace metals in small samples of size-fractionated particulate matter: phytoplankton metals off central California, Mar. Chem., 67, 233-247, doi:10.1016/S0304-4203(99)00060-2, 1999.

Doucet, S., Scoates, J. S., Weis, D., and Giret, A.: Constraining the components of the Kerguelen mantle plume: A Hf-Pb-Sr$\mathrm{Nd}$ isotopic study of picrites and high-MgO basalts from the Kerguelen Archipelago, Geochem. Geophy. Geosy., 6, Q04007, doi:10.1029/2004GC000806, 2005.

Ellwood, M. J. and van den Berg, C. M. G.: Determination of organic complexation of cobalt in seawater by cathodic stripping voltammetry, Mar. Chem., 75, 33-47, 2001.

Hausrath, E. M., Neaman, A., and Brantley, S. L.: Elemental release rates from dissolving basalt and granite with and without organic ligands, Am. J. Sci., 309, 633-660, doi:10.2475/08.2009.01, 2009.

Heggie, D. and Lewis, T.: Cobalt in pore waters of marine sediments, Nature, 311, 453-455, 1984.

Jeandel, C., Pradoux, C., Zhang, Y., van Beek, P., Lacan, F., and Pierce, M. J. a. C.: Land-to-ocean processes on the Kerguelen plateau traced by REE concentrations and Nd isotopic composition, 43rd International Liège Colloquium on Ocean Dynamics "Traces \& Tracers", Liége (Belgium), May 2011.

Johnson, K. S., Stout, P. M., Berelson, W. M., and SakamotoArnold, C. M.: Cobalt and Copper Distributions in the Waters of Santa-Monica Basin, California, Nature, 332, 527-530, doi:10.1038/332527a0, 1988.

Johnson, K. S., Gordon, R. M., and Coale, K. H.: What controls dissolved iron concentrations in the world ocean?, Mar. Chem., 57, 137-161, 1997.

Martin, J. H., Coale, K. H., Johnson, K. S., Fitzwater, S. E., Gordon, R. M., Tanner, S. J., Hunter, C. N., Elrod, V. A., Nowicki, J. L., Coley, T. L., Barber, R. T., Lindley, S., Watson, A. J., Van Scoy, K., Law, C. S., Liddicoat, M. I., Ling, R., Stanton, T., Stockel, J., Collins, C., Anderson, A., Bidigare, R., Ondrusek, M., Latasa, M., Millero, F. J., Lee, K., Yao, W., Zhang, J. Z., Friedrich, G., Sakamoto, C., Chavez, F., Buck, K., Kolber, Z., Greene, R., Falkowski, P., Chisholm, S. W., Hoge, F., Swift, R., Yungel, J., Turner, S., Nightingale, P., Hatton, A., Liss, P., and
Tindale, N. W.: Testing the Iron hypothesis in ecosystems of the equatorial Pacific Ocean, Nature, 371, 123-129, 1994.

Moore, W. S., Ussler, W., and Paull, C. K.: Short-lived radium isotopes in the Hawaiian margin: Evidence for large fluid fluxes through the Puna Ridge, Mar. Chem., 109, 421-430, doi:10.1016/j.marchem.2007.09.010, 2008.

Morel, F. M. M., Milligan, A. J., Saito, M. A., Heinrich, D. H., and Karl, K. T.: Marine bioinorganic chemistry: The role of trace metals in the oceanic cycles of major nutrients, 113-143, in: Treatise on geochemistry, edited by: Holland, H. D. and Turekian, K. K., v. 6, Elsevier, 2003.

Noble, A. E., Saito, M. A., Maiti, K., and Benitez-Nelson, C. R.: Cobalt, manganese, and iron near the Hawaiian Islands: A potential concentrating mechanism for cobalt within a cyclonic eddy and implications for the hybrid-type trace metals, Deep-Sea Res. Pt. II, 55, 1473-1490, doi:10.1016/j.dsr2.2008.02.010, 2008.

Noble, A. E., Lamborg, C. H., Ohnemus, D. C., Lam, P. J., Goepfert, T. J., Measures, C. I., Frame, C. H., Casciotti, K. L., DiTullio, G. R., Jennings, J., and Saito, M. A.: Basin-scale inputs of cobalt, iron, and manganese from the Benguela-Angola front to the South Atlantic Ocean, Limnol. Oceanogr., 57, 989-1010, 2012.

Park, Y. H., Fuda, J. L., Durand, I., and Garabato, A. C. N.: Internal tides and vertical mixing over the Kerguelen Plateau, Deep-Sea Res. Pt. II, 55, 582-593, doi:10.1016/j.dsr2.2007.12.027, 2008a.

Park, Y. H., Roquet, F., Durand, I., and Fuda, J. L.: Large-scale circulation over and around the Northern Kerguelen Plateau, DeepSea Res. Pt. II, 55, 566-581, doi:10.1016/j.dsr2.2007.12.030, 2008b.

Park, Y. H., Vivier, F., Roquet, F., and Kestenare, E.: Direct observations of the ACC transport across the Kerguelen Plateau, Geophys. Res. Lett., 36, L18603, doi:10.1029/2009GL039617, 2009.

Saito, M. A. and Moffett, J. W.: Complexation of cobalt by natural organic ligands in the Sargasso Sea as determined by a new highsensitivity electrochemical cobalt speciation method suitable for open ocean work, Mar. Chem., 75, 49-68, 2001.

Saito, M. A. and Moffett, J. W.: Temporal and spatial variability of cobalt in the Atlantic Ocean, Geochim. Cosmochim. Ac., 66, 1943-1953, 2002.

Saito, M. A., Moffett, J. W., and DiTullio, G. R.: Cobalt and nickel in the Peru upwelling region: A major flux of labile cobalt utilized as a micronutrient, Global Biogeochem. Cy., 18, GB4030, doi:10.1029/2003GB002216, 2004.

Saito, M. A., Goepfert, T. J., Noble, A. E., Bertrand, E. M., Sedwick, P. N., and DiTullio, G. R.: A seasonal study of dissolved cobalt in the Ross Sea, Antarctica: micronutrient behavior, absence of scavenging, and relationships with $\mathrm{Zn}, \mathrm{Cd}$, and $\mathrm{P}$, Biogeosciences, 7, 4059-4082, doi:10.5194/bg-7-4059-2010, 2010.

Sarthou, G., Vincent, D., Christaki, U., Obernosterer, I., Timmermans, K. R., and Brussaard, C. P. D.: The fate of biogenic iron during a phytoplankton bloom induced by natural fertilisation: Impact of copepod grazing, Deep-Sea Res. Pt. II, 55, 734-751, doi:10.1016/j.dsr2.2007.12.033, 2008.

Shelley, R. U., Zachhuber, B., Sedwick, P. N., Worsfold, P. J., and Lohan, M. C.: Determination of total dissolved cobalt in UV-irradiated seawater using flow injection with chemiluminescence detection., Limnol. Oceanogr., 8, 352-362, doi:10.1029/2009JC005880, 2010. 
Shelley, R. U., Sedwick, P. N., Bibby, T. S., Cabedo-Sanz, P., Church, T. M., Johnson, R. J., Macey, A. I., Marsay, C. M., Sholkovitz, E. R., Ussher, S. J., Worsfold, P. J., and Lohan, M. C.: Controls on dissolved cobalt in surface waters of the Sargasso Sea: Comparisons with iron and aluminum, Global Biogeochem. Cy., 26, 16 pp., GB2020, 2012.

Sunda, W. and Huntsman, S. A.: Cobalt and zinc interreplacement in marine phytoplankton: Biological and geochemical implications, Limnol. Oceanogr., 40, 1404-1417, 1995.

Thuróczy, C.-E., Boye, M., and Losno, R.: Dissolution of cobalt and zinc from natural and anthropogenic dusts in seawater, Biogeosciences, 7, 1927-1936, doi:10.5194/bg-7-1927-2010, 2010.

Uitz, J., Claustre, H., Griffiths, F. B., Ras, J., Garcia, N., and Sandroni, V.: A phytoplankton class-specific primary production model applied to the Kerguelen Islands region (Southern Ocean), Deep-Sea Res. Pt. I, 56, 541-560, 2009. van Beek, P., Bourquin, M., Reyss, J. L., Souhaut, M., Charette, M. A., and Jeandel, C.: Radium isotopes to investigate the water mass pathways on the Kerguelen Plateau (Southern Ocean), Deep-Sea Res. Pt. II, 55, 622-637, doi:10.1016/j.dsr2.2007.12.025, 2008.

Viollier, E., Bombled, B., Sangiardi, P., and Scouarnec, L.: Biogeochemistry of Kerguelen Plateau sediments, KEOPS cruise report, IPEV, OCE/2005/01, 107-116, 2005.

Weis, D., Frey, F. A., Schlich, R., Schaming, M., Montigny, R., Damasceno, D., Mattielli, N., Nicolaysen, K. E., and Scoates, J. S.: Trace of the Kerguelen mantle plume: Evidence from seamounts between the Kerguelen Archipelago and Heard Island, Indian Ocean, Geochem. Geophy. Geosy., 3, 1033, doi:10.1029/2001GC000251, 2002.

Zhang, Y., Lacan, F., and Jeandel, C.: Dissolved rare earth elements tracing lithogenic inputs over the Kerguelen Plateau (Southern Ocean), Deep-Sea Res. Pt. II, 55, 638-652, doi:10.1016/j.dsr2.2007.12.029, 2008. 